\title{
LANMAS Gap Analysis Report
}

C. Parrish, B. Watson, N. Storch, W. Yee and V. Okuda

\section{August 25, 2000}

\section{Lawrence}

Livermore

National

Laboratory

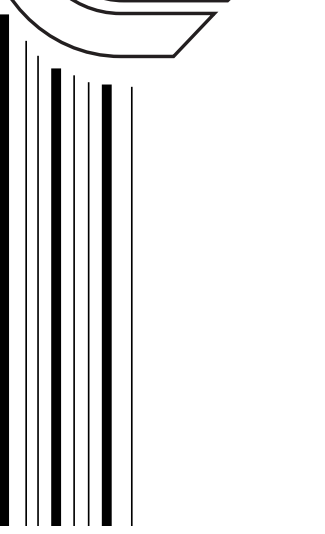




\section{DISCLAIMER}

This document was prepared as an account of work sponsored by an agency of the United States Government. Neither the United States Government nor the University of California nor any of their employees, makes any warranty, express or implied, or assumes any legal liability or responsibility for the accuracy, completeness, or usefulness of any information, apparatus, product, or process disclosed, or represents that its use would not infringe privately owned rights. Reference herein to any specific commercial product, process, or service by trade name, trademark, manufacturer, or otherwise, does not necessarily constitute or imply its endorsement, recommendation, or favoring by the United States Government or the University of California. The views and opinions of authors expressed herein do not necessarily state or reflect those of the United States Government or the University of California, and shall not be used for advertising or product endorsement purposes.

Work performed under the auspices of the U. S. Department of Energy by the University of California Lawrence Livermore National Laboratory under Contract W-7405-Eng-48.

This report has been reproduced directly from the best available copy.

Available to DOE and DOE contractors from the

Office of Scientific and Technical Information

P.O. Box 62, Oak Ridge, TN 37831

Prices available from (423) 576-8401

http://apollo.osti.gov/bridge/

Available to the public from the National Technical Information Service

U.S. Department of Commerce 5285 Port Royal Rd., Springfield, VA 22161 http://www.ntis.gov/

OR

Lawrence Livermore National Laboratory Technical Information Department's Digital Library http://www.llnl.gov/tid/Library.html 


\section{LANMAS Gap Analysis Report}

\section{Charles Parrish \\ Bruce Watson \\ Nancy Storch \\ Wally Yee \\ Vira Okuda}

August 25, 2000

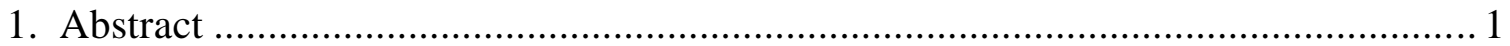

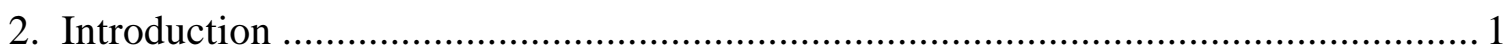

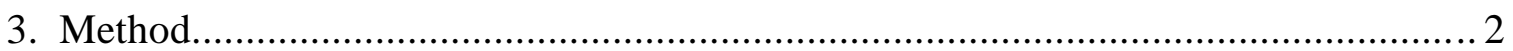

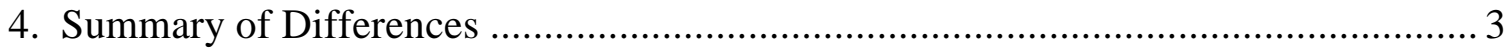

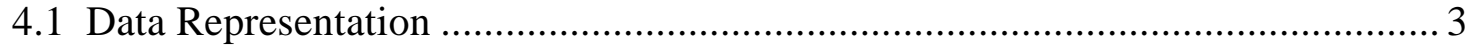

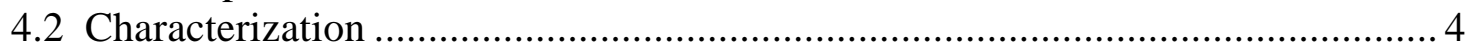

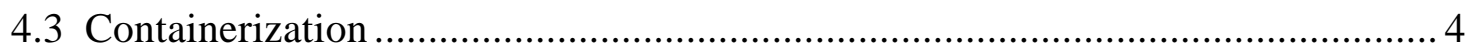

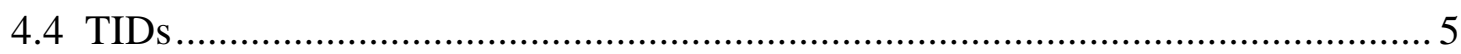

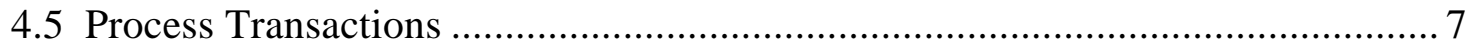

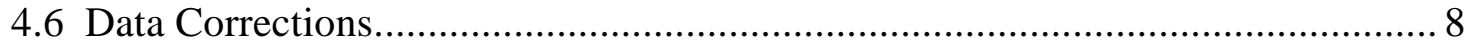

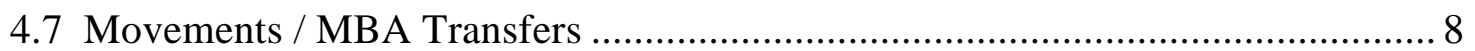

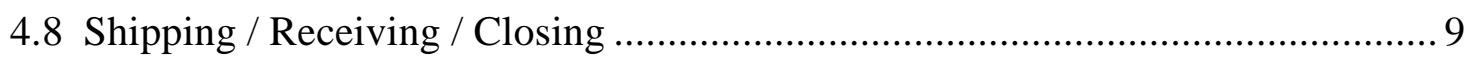

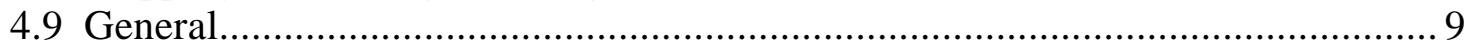

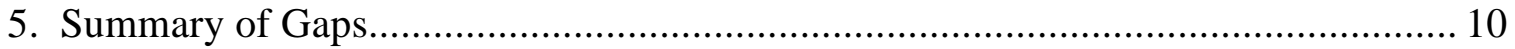

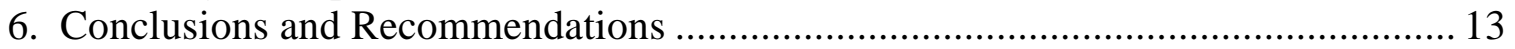

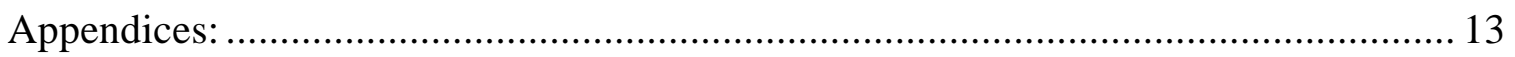





\section{Abstract}

In July, 2000, the COMATS Team, with the assistance of a representative of the LANMAS development team from Savannah River, performed an evaluation to enumerate and qualify differences between the current LANMAS functionality and LLNL requirements as implemented by COMATS. The differences found range from minor to serious deficiencies of LANMAS in relation to current LLNL MC\&A practice. Therefore, we recommend a gradual integration of LANMAS into a hybrid system which uses LANMAS to satisfy DOE / NNSA MC\&A and reporting requirements and uses COMATS to satisfy LLNL-specific MC\&A and operational requirements.

\section{Introduction}

It is very clear that the Local Area Network Materials Accountability System (LANMAS), which was developed at the Westinghouse Savannah River Company (WSRC), supports procedures that are very different than those used at LLNL. Many LLNL procedures are implemented through the Controlled Materials Accountability and Tracking System (COMATS); others are implemented solely administratively. It will take a great deal of effort on both LANMAS' part and LLNL's part to make LLNL's transition to LANMAS as smooth as possible.

We recognize that LANMAS must support many other user sites besides LLNL and adjustments to LANMAS that favor LLNL's procedures can likely be made only if there is sufficient benefit to the other user sites as well. Consequently, a complete transition from COMATS to LANMAS in the foreseeable future will not be possible.

This report supports a recommendation to proceed with a phased integration of LANMAS into COMATS with a hybrid result that would:

- $\quad$ Allow the Materials Accountability Group (MAG) to use LANMAS to perform month-end closing activities.

- $\quad$ Allow users to use the existing COMATS user-interface to perform operations involving items in the inventory - shipping, receiving, movements, processing, adjustment/editing, and TID functions. Such operations would be translated to LANMAS transactions and applied to the LANMAS database

- $\quad$ Allow users to use LANMAS to obtain standard LANMAS programmed reports, such as book and physical inventory reports, ledger reports, NMMSS reports, etc., and to use COMATS to obtain LLNL-specific reports, such as workstation inventory reports, item history and genealogy reports, and to perform queries. 
- $\quad$ As the COMATS user-interface is reengineered to run on modern PCworkstations, and to be easier to learn and use, evaluate the LANMAS userinterface as one of a number of alternatives, taking into account enhancements made to LANMAS and its user-interface as a result of the feedback contained in this report.

Any implementation of LANMAS at LLNL requires the deployment of a module, called the Automated Programming Interface, that would allow users, using an interface other than the LANMAS user-interface. e.g., COMATS to: 1) create transactions to be applied to the LANMAS database; and 2) request LANMAS to generate standard LANMAS reports.

Section 3 of this report describes the methodology used to compare LANMAS and COMATS. Section 4 identifies key differences between the two systems. A summary of key differences, or "gaps", which preclude complete LLNL transition from COMATS to LANMAS is provided in Section 5. Section 6 presents recommendations and conclusions.

\section{Method}

In order to provide a scope of a possible near-term integration of LANMAS and COMATS, the COMATS Team, with the assistance from members of the Materials Accountability Group, the Operations Group, and volunteer Fissile Material Handlers from the Plutonium Facility, compared COMATS with LANMAS to identify the "gaps," which are identified as LANMAS deficiencies.

The "gap analysis" was done in two parts:

- $\quad$ Desktop Analysis - This was done by: 1) enumerating LLNL requirements as implemented by COMATS; 2) enumerating LANMAS functions and features from the LANMAS User Guide and the LANMAS Data Dictionary; and 3) establishing a correspondence between an LLNL requirement and one or more LANMAS functions / features.

- Usability Testing - This was done with the help of Helen Howell, a representative from the WSRC LANMAS development team. Her task was to: 1) familiarize a select group of COMATS users with the use of LANMAS; and 2) assist in the execution of tasks from a use-case scenario designed to mimic the receipt of an item, some processing, and the shipment of the results. Each user, in some cases a pair of users, was assigned some specific tasks to do; these tasks were approximately equivalent to tasks they normally perform in COMATS. While Helen did provide assistance during each test session when needed, at least two other individuals observed and took notes. Following the session, the observation team leader interviewed the user(s). The observation team, including Helen Howell, then gathered their thoughts regarding the users' reaction to LANMAS and its interface. See Appendix A for further details on the method and a summary of the results. 


\section{Summary of Differences}

It has been known from the outset the LANMAS is different than COMATS. One result of the "gap analysis" was the enumeration of these differences.

Basically, COMATS-LANMAS differences fall into one of three types:

1. COMATS and LANMAS share the same functionality, but they are implemented differently.

2. LANMAS has superior functionality.

3. LANMAS is deficient. These deficiencies are the "gaps."

Differences fall into the following categories: 1) Data Representation;

2) Characterization; 3) Containerization; 4) TIDs; 5) Process Transactions; 6) Data Corrections; 7) Movements and MBA Transfers; 8) Shipping, Receiving, and Closing activities; and 9) General differences. The differences are discussed in further detail, with discussion of serious deficiencies deferred to Section 5.

\subsection{Data Representation}

\begin{tabular}{|l|l|l|}
\hline & \multicolumn{1}{|c|}{ COMATS } & \multicolumn{1}{|c|}{ LANMAS } \\
\hline 1 & $\begin{array}{l}\text { Represents nuclear material using the } \\
17 \text { DOE-defined material types (MT). }\end{array}$ & $\begin{array}{l}\text { Represents nuclear material using element } \\
\text { and isotope designations. Material types } \\
\text { are used only for reporting purposes. }\end{array}$ \\
\hline 2 & Balances transactions by MT. & Balances transactions by isotope. \\
\hline 3 & $\begin{array}{l}\text { User need be aware of summary } \\
\text { material type (SMT). }\end{array}$ & $\begin{array}{l}\text { User need be aware of detail material type } \\
\text { (DMT). }\end{array}$ \\
\hline 4 & $\begin{array}{l}\text { Awareness of isotopic composition is } \\
\text { optional. }\end{array}$ & $\begin{array}{l}\text { Awareness of isotopic composition is } \\
\text { mandatory. }\end{array}$ \\
\hline 5 & $\begin{array}{l}\text { Can track only uranium, plutonium, } \\
\text { and americium isotopes. }\end{array}$ & $\begin{array}{l}\text { Can track any element in the Periodic } \\
\text { Table; can track any isotope in the Table } \\
\text { of Nuclides. }\end{array}$ \\
\hline 6 & $\begin{array}{l}\text { Depleted, Normal uranium weights } \\
\text { entered in kilograms. }\end{array}$ & $\begin{array}{l}\text { Depleted, Normal uranium weights } \\
\text { entered in grams. }\end{array}$ \\
\hline 7 & $\begin{array}{l}\text { Tracks sealed sources as a separate } \\
\text { application. }\end{array}$ & $\begin{array}{l}\text { Can track sealed sources as part of the } \\
\text { LANMAS application. }\end{array}$ \\
\hline 8 & $\begin{array}{l}\text { Tracks classified parts as a separate } \\
\text { application. }\end{array}$ & $\begin{array}{l}\text { Can track classified parts by creating } \\
\text { "elements" and "isotopes" that represent } \\
\text { classified parts. }\end{array}$ \\
\hline 9 & $\begin{array}{l}\text { All items on inventory must have a } \\
\text { unique name assigned by the user. }\end{array}$ & $\begin{array}{l}\text { Different items in the current inventory } \\
\text { need not have a unique name assigned by }\end{array}$ \\
\hline
\end{tabular}




\begin{tabular}{|l|l|l|}
\hline & & the user. \\
\hline 10 & Uses Quota to map to DOE project. & Uses DOE project directly. \\
\hline
\end{tabular}

\subsection{Characterization}

\begin{tabular}{|c|c|c|}
\hline & COMATS & LANMAS \\
\hline 1 & $\begin{array}{l}\text { Use Purpose (P), Detail Purpose (DP), } \\
\text { Form (F), Form Detail (FD), Shape } \\
\text { (S), and set of Contaminants (C1-C3) } \\
\text { to characterize an item. }\end{array}$ & $\begin{array}{l}\text { Uses Item Description Code (IDC) to } \\
\text { characterize an item. }\end{array}$ \\
\hline 2 & $\begin{array}{l}\text { One } \mathrm{P}, \mathrm{DP} \text {, and } \mathrm{S} \text { for each item; one } \mathrm{F} \text {, } \\
\mathrm{FD} \text {, and } \mathrm{C} 1-\mathrm{C} 3 \text { for each item's } \\
\text { material type. }\end{array}$ & One IDC for each item. \\
\hline 3 & $\begin{array}{l}\mathrm{P}+\mathrm{DP}+\mathrm{F}+\mathrm{FD}->\mathrm{COEI} \text { for each } \\
\text { material type. }\end{array}$ & IDC -> COEI for each item. \\
\hline 4 & $\begin{array}{l}\text { Scrap } \mathrm{P}+\mathrm{DP}+\mathrm{F}+\mathrm{FD}->\text { ANSI Scrap } \\
\text { Code for each uranium and plutonium } \\
\text { material type. }\end{array}$ & $\begin{array}{l}\text { User to enter ANSI Scrap Code as a } \\
\text { separate field. }\end{array}$ \\
\hline 5 & $\begin{array}{l}\text { Tree-structured menu for selecting P, } \\
\text { DP, F, and FD: } \\
\text { DP menu based on selected P } \\
\text { F menu based on selected P, DP, MT } \\
\text { FD menu based on selected P, DP, F, } \\
\text { MT. }\end{array}$ & $\begin{array}{l}\text { Linear structured menu for selecting IDC. } \\
\text { User can select any IDC, regardless of } \\
\text { material type and whether or not the } \\
\text { resulting COEI is valid for the item's } \\
\text { material type. }\end{array}$ \\
\hline
\end{tabular}

\subsection{Containerization}

\begin{tabular}{|l|l|l|}
\hline & \multicolumn{1}{|c|}{ COMATS } & \multicolumn{1}{|c|}{ LANMAS } \\
\hline 1 & Use Group/Ungroup function & Use Load/Unload function \\
\hline 2 & $\begin{array}{l}\text { Group name created at time items are } \\
\text { grouped. }\end{array}$ & $\begin{array}{l}\text { Container must exist prior to loading. } \\
\text { Container must be in same MBA as items } \\
\text { to be loaded. }\end{array}$ \\
\hline 3 & $\begin{array}{l}\text { Group name goes away when all items } \\
\text { removed. }\end{array}$ & $\begin{array}{l}\text { Container is retained until explicitly } \\
\text { removed. }\end{array}$ \\
\hline 4 & Groups may not be nested. & $\begin{array}{l}\text { Containers may be nested to any number } \\
\text { of levels. }\end{array}$ \\
\hline 5 & $\begin{array}{l}\text { Any number of container and } \\
\text { packaging types may be associated } \\
\text { with each item when item created as } \\
\text { the result of a process transaction. } \\
\text { Nesting is determined by order of } \\
\text { selection (innermost to outermost). }\end{array}$ & $\begin{array}{l}\text { Container type is associated with } \\
\text { container at the time the container is } \\
\text { created. Packing material type is } \\
\text { associated with items and container when } \\
\text { items are loaded into the container. }\end{array}$ \\
\hline 6 & $\begin{array}{l}\text { Group names must be unique in the } \\
\text { Container names need not be unique. }\end{array}$ \\
\hline
\end{tabular}




\begin{tabular}{|c|c|c|}
\hline & current inventory. & \\
\hline 7 & $\begin{array}{l}\text { Users may perform general edits and } \\
\text { data corrections on a member of a } \\
\text { group. }\end{array}$ & $\begin{array}{l}\text { Users may perform no transaction, except } \\
\text { TID Apply and Destroy, on any item } \\
\text { while inside a container. }\end{array}$ \\
\hline 8 & $\begin{array}{l}\text { Gross and tare weight is associated } \\
\text { with an item and must be entered } \\
\text { when item is created. }\end{array}$ & $\begin{array}{l}\text { Gross and tare weight are associated with } \\
\text { a container and are entered when the } \\
\text { container is created. }\end{array}$ \\
\hline 9 & $\begin{array}{l}\text { Primary and secondary container and } \\
\text { packaging types (first two levels of } \\
\text { each) easily obtainable }{ }^{1} \text { from the } \\
\text { inventory. }\end{array}$ & $\begin{array}{l}\text { Only innermost container and packaging } \\
\text { type easily obtainable from the inventory. } \\
\text { Other than innermost container and } \\
\text { packaging information would be difficult } \\
\text { to obtain. }{ }^{2}\end{array}$ \\
\hline
\end{tabular}

\subsection{TIDs}

\begin{tabular}{|c|c|c|}
\hline & COMATS & LANMAS \\
\hline 1 & TID number is alpha prefix + numeric & TID number is prefix + numeric + suffix. \\
\hline 2 & $\begin{array}{l}\text { TID number may be up to } 5 \text { characters } \\
\text { long }\end{array}$ & TID number length is configurable \\
\hline 3 & $\begin{array}{l}\text { User sets TID number prefix when } \\
\text { entering new TIDs. }\end{array}$ & $\begin{array}{l}\text { System administrator defines acceptable } \\
\text { TID number prefixes and suffixes when } \\
\text { defining TID types. }\end{array}$ \\
\hline 4 & $\begin{array}{l}\text { Number of digits in numeric is } 5 \\
\text { minus the length of the prefix. }\end{array}$ & $\begin{array}{l}\text { System administrator sets the number of } \\
\text { digits in the numeric. }\end{array}$ \\
\hline 5 & $\begin{array}{l}\text { "Level" is associated with TIDs. We } \\
\text { talk about inner and outer seals. }\end{array}$ & $\begin{array}{l}\text { "Level" is associated with containers. We } \\
\text { talk about inner and outer containers. }\end{array}$ \\
\hline 6 & $\begin{array}{l}\text { Outer TID information easily } \\
\text { obtainable. }\end{array}$ & Outer TID information difficult to obtain. \\
\hline 7 & $\begin{array}{l}\text { TIDs may be applied to items, } \\
\text { workstations, or rooms. }\end{array}$ & $\begin{array}{l}\text { TIDs may be applied to items, containers, } \\
\text { or "locations". This may imply that TIDs } \\
\text { may be applied to buildings and rooms, as } \\
\text { well as workstations. }\end{array}$ \\
\hline 8 & $\begin{array}{l}\text { One TID may be applied to any } \\
\text { number of items. }\end{array}$ & $\begin{array}{l}\text { One TID may be applied to only one item } \\
\text { or one container. Multiple items and } \\
\text { containers must be placed inside of a } \\
\text { larger container and the TID applied to } \\
\text { that container. }\end{array}$ \\
\hline 9 & $\begin{array}{l}\text { One TID may be applied to any } \\
\text { number of workstations. }\end{array}$ & $\begin{array}{l}\text { One TID may be applied to one location. } \\
\text { Since locations may be defined up to } 5 \\
\text { levels, it may be possible group }\end{array}$ \\
\hline
\end{tabular}

\footnotetext{
${ }^{1}$ This means that the information may be obtained by entering a single database query.

${ }^{2}$ This means that a programmer would have to write a program to obtain this information. However, once written, the program is reusable with different input parameters, unlike single interactive queries or scripts which require modification for different inputs.
} 


\begin{tabular}{|c|c|c|}
\hline & & $\begin{array}{l}\text { workstations into a higher level location } \\
\text { (e.g., room or "box") and apply the TID to } \\
\text { that location. }\end{array}$ \\
\hline 10 & $\begin{array}{l}\text { Once a TID is issued to an MBA, it } \\
\text { may be applied to any item, regardless } \\
\text { of MBA. }\end{array}$ & $\begin{array}{l}\text { Once a TID is issued to an MBA, it may } \\
\text { be applied only to items in that MBA. }\end{array}$ \\
\hline 11 & $\begin{array}{l}\text { It is possible to re-issue TIDs to a } \\
\text { different user. }\end{array}$ & $\begin{array}{l}\text { TIDs must be returned to "for use" before } \\
\text { they can be re-issued. }\end{array}$ \\
\hline 12 & $\begin{array}{l}\text { It is possible to re-issue TIDs to a } \\
\text { different MBA. }\end{array}$ & $\begin{array}{l}\text { TIDs must be returned to "for use", } \\
\text { transferred to the desired MBA, and then } \\
\text { re-issued. }\end{array}$ \\
\hline 13 & Enter TIDs function. & Receive TIDs function. \\
\hline 14 & Remove TIDs function. & Destroy TIDs function (already applied). \\
\hline 15 & Void TIDs function. & $\begin{array}{l}\text { Destroy TIDs function (not already } \\
\text { applied). }\end{array}$ \\
\hline 16 & $\begin{array}{l}\text { Assumes apply and destroy entered by } \\
\text { actual user. MAG user may apply and } \\
\text { destroy on behalf of others. }\end{array}$ & $\begin{array}{l}\text { Assumes all apply and destroy entered by } \\
\text { clerk on behalf of others. }\end{array}$ \\
\hline 17 & $\begin{array}{l}\text { Any TID user may be issued, may } \\
\text { apply, or may remove TIDs in any } \\
\text { MBA. }\end{array}$ & $\begin{array}{l}\text { TID users placed into three privilege } \\
\text { groups by MBA. }\end{array}$ \\
\hline 18 & $\begin{array}{l}\text { MBA not an issue when entering new } \\
\text { TIDs. }\end{array}$ & $\begin{array}{l}\text { New TIDs may be received into only one } \\
\text { MBA. }\end{array}$ \\
\hline 19 & $\begin{array}{l}\text { Only one physical TID operation } \\
\text { (apply or remove) may be entered at } \\
\text { one time. }\end{array}$ & $\begin{array}{l}\text { Any number of physical TID operations } \\
\text { may be entered at one time. }\end{array}$ \\
\hline 20 & $\begin{array}{l}\text { Options available for correcting TID } \\
\text { application or removal: } \\
\text { Correcting TID applied to an item } \\
\text { Applying an interior TID } \\
\text { Merging sets of items under TIDs } \\
\text { Undoing an apply } \\
\text { Undoing a removal. }\end{array}$ & $\begin{array}{l}\text { Options available for correcting TID } \\
\text { application or removal: } \\
\text { Undo apply and return to "for use" } \\
\text { Undo apply and return re-issue } \\
\text { Undo destroy and return to "for use" } \\
\text { Undo destroy and re-issue } \\
\text { Re-apply applied TID to another item } \\
\text { Re-apply destroyed TID to another } \\
\text { item. }\end{array}$ \\
\hline 21 & $\begin{array}{l}\text { To correct or undo an apply or } \\
\text { removal, the user needs to know only } \\
\text { ONE item that the TID is applied to. } \\
\text { To undo an apply or removal, the user } \\
\text { may enter the TID. }\end{array}$ & $\begin{array}{l}\text { To correct or undo an apply or removal, } \\
\text { the user must know the transaction ID of } \\
\text { the transaction to be corrected or undone. }\end{array}$ \\
\hline 22 & $\begin{array}{l}\text { A TID may be applied to items not in } \\
\text { the inventory. }\end{array}$ & $\begin{array}{l}\text { A TID may be applied only to items in the } \\
\text { inventory. }\end{array}$ \\
\hline 23 & $\begin{array}{l}\text { When the user ships an NM item to } \\
\text { which a TID is applied, the TID is also } \\
\text { "shipped". }\end{array}$ & $\begin{array}{l}\text { The user may perform a separate } \\
\text { transaction to "ship" a TID. }\end{array}$ \\
\hline
\end{tabular}




\subsection{Process Transactions}

\begin{tabular}{|c|c|c|}
\hline & COMATS & LANMAS \\
\hline 1 & $\begin{array}{l}\text { Process types are: } \\
\text { Assemble (many-to-one) } \\
\text { Split (one-to-many) } \\
\text { Alter / data correction (one-to-one) } \\
\text { Generic / transform (many-to- } \\
\text { many). }\end{array}$ & $\begin{array}{l}\text { Process types are: } \\
\text { Mix (many-to-one) } \\
\text { Split (one-to-many) } \\
\text { Transfer (one-to-one). }\end{array}$ \\
\hline 2 & $\begin{array}{l}\text { Paradigm: } \\
\text { Source items (parents) are } \\
\text { processed to become product items } \\
\text { (children). }\end{array}$ & $\begin{array}{l}\text { Paradigm: } \\
\text { Material is moved from source items to } \\
\text { destination items. }\end{array}$ \\
\hline 3 & "Alter" means item is modified. & $\begin{array}{l}\text { "Transfer" means material is moved from } \\
\text { one item to another. }\end{array}$ \\
\hline 4 & $\begin{array}{l}\text { Source items are assumed to be } \\
\text { destroyed, even though products may } \\
\text { have same serial numbers. }\end{array}$ & $\begin{array}{l}\text { Source items remain unless explicitly } \\
\text { removed by the user. }\end{array}$ \\
\hline 5 & $\begin{array}{l}\text { Product items are assumed to be new } \\
\text { items, even though they may have } \\
\text { same serial numbers as the sources. }\end{array}$ & $\begin{array}{l}\text { Destination items may or may not already } \\
\text { exist and contain material before the } \\
\text { transaction. }\end{array}$ \\
\hline 6 & $\begin{array}{l}\text { All products must be characterized. } \\
\text { Default characterization allowed only } \\
\text { for split and (MAG) transform. }\end{array}$ & $\begin{array}{l}\text { User enters IDC (and ANSI Scrap code) } \\
\text { only for created items. User changes IDC } \\
\text { and ANSI Scrap code through another } \\
\text { function. }\end{array}$ \\
\hline 7 & $\begin{array}{l}\text { Source items may be assigned to } \\
\text { different DOE projects; for MAG } \\
\text { transform, user may assign products to } \\
\text { different DOE projects. Some project } \\
\text { changes may be implicit. }\end{array}$ & $\begin{array}{l}\text { All items involved (source and } \\
\text { destination) in process must be assigned } \\
\text { to the same DOE project. All project } \\
\text { changes must be explicit. }\end{array}$ \\
\hline 8 & $\begin{array}{l}\text { "Left over" material is automatically } \\
\text { assigned to "box loss" items in B332 } \\
\text { and to "write-off" items for MAG } \\
\text { transforms. }\end{array}$ & $\begin{array}{l}\text { "Left over" material remains in source } \\
\text { items until the items are explicitly } \\
\text { removed. Using "box loss" and "write- } \\
\text { offs" very difficult. }\end{array}$ \\
\hline 9 & $\begin{array}{l}\text { Rounding to NMMSS reporting units } \\
\text { is done for each transaction. "Round- } \\
\text { offs" are automatically generated for } \\
\text { each transaction to make NMMSS } \\
\text { weights balance. }\end{array}$ & $\begin{array}{l}\text { All rounding takes place at month-end } \\
\text { balance. No "round-offs" are generated } \\
\text { for any transactions. }\end{array}$ \\
\hline 10 & $\begin{array}{l}\text { Rounding is at the item level; } \\
\text { NMMSS totals result from a "round, } \\
\text { then add" scheme. }\end{array}$ & $\begin{array}{l}\text { NMMSS totals result from an "add, then } \\
\text { round" scheme for items grouped by detail } \\
\text { material type, COEI, and DOE project } \\
\text { number. }\end{array}$ \\
\hline 11 & For Assembly, Split, and Alter, the & For Mix and Transfer, the user enters the \\
\hline
\end{tabular}




\begin{tabular}{|l|l|l|}
\hline & user enters the weight of the products. & new weight of the source items \\
\hline 12 & $\begin{array}{l}\text { For Assembly, Split, and Alter, the } \\
\text { user enters the element weight only; } \\
\text { of the destination items. }\end{array}$ \\
$\begin{array}{l}\text { the isotope weight and enrichment are } \\
\text { automatically calculated. }\end{array}$ & $\begin{array}{l}\text { The user must enter both the element and } \\
\text { isotope weights. }\end{array}$ \\
\hline 13 & $\begin{array}{l}\text { Defaults are provided for product } \\
\text { weights }\end{array}$ & $\begin{array}{l}\text { Little assistance, if any, is provided for } \\
\text { weights }\end{array}$ \\
\hline
\end{tabular}

\subsection{Data Corrections}

\begin{tabular}{|l|l|l|}
\hline & \multicolumn{1}{|c|}{ COMATS } & \multicolumn{1}{c|}{ LANMAS } \\
\hline 1 & A user may update an item. & A user may add, delete, or update an item. \\
\hline 2 & $\begin{array}{l}\text { A MAG user assigns the Type } \\
\text { Inventory Change (TIC) code at } \\
\text { month-end closing when write-offs are } \\
\text { removed and reported to NMMSS. }\end{array}$ & $\begin{array}{l}\text { The user must assign the TIC code when } \\
\text { entering the transaction. }\end{array}$ \\
\hline
\end{tabular}

\subsection{Movements / MBA Transfers}

\begin{tabular}{|c|c|c|}
\hline & COMATS & LANMAS \\
\hline 1 & $\begin{array}{l}\text { Movements may be either one-step or } \\
\text { two-step, configurable by the system } \\
\text { administrator. }\end{array}$ & $\begin{array}{l}\text { All movements within an MBA are one- } \\
\text { step } \\
\text { All movements between MBAs are two- } \\
\text { step. }\end{array}$ \\
\hline 2 & $\begin{array}{l}\text { A user can move many items from one } \\
\text { source to one destination location. }\end{array}$ & $\begin{array}{l}\text { A user can move many items, each from a } \\
\text { different source, and each to a different } \\
\text { destination. }\end{array}$ \\
\hline 3 & $\begin{array}{l}\text { User authorization is to the room or } \\
\text { workstation level. }\end{array}$ & $\begin{array}{l}\text { User authorization is to the MBA and } \\
\text { subMBA level. }\end{array}$ \\
\hline 4 & $\begin{array}{l}\text { Criticality limit, safeguards limit, and } \\
\text { ratio limit checking is available. }\end{array}$ & No mass limit checking is available. \\
\hline 5 & $\begin{array}{l}\text { Two-step movements are considered } \\
\text { one transaction and have one } \\
\text { transaction ID. }\end{array}$ & $\begin{array}{l}\text { Each step in a two-step movement is a } \\
\text { separate transaction and has its own } \\
\text { transaction ID and TIC. }\end{array}$ \\
\hline
\end{tabular}




\subsection{Shipping / Receiving / Closing}

\begin{tabular}{|l|l|l|}
\hline & \multicolumn{1}{|c|}{ COMATS } & \multicolumn{1}{c|}{ LANMAS } \\
\hline 1 & $\begin{array}{l}\text { Requires received AL-131 files to } \\
\text { contain detail material types. }\end{array}$ & $\begin{array}{l}\text { Requires received AL-131 files to contain } \\
\text { summary material types. }\end{array}$ \\
\hline 2 & $\begin{array}{l}\text { Requires switching between captive } \\
\text { and non-captive accounts for editing } \\
\text { some files. }\end{array}$ & $\begin{array}{l}\text { User can create separate window in same } \\
\text { session for file editing. }\end{array}$ \\
\hline 3 & $\begin{array}{l}\text { Summary line numbers in AL-131 } \\
\text { files are not required. }\end{array}$ & $\begin{array}{l}\text { Summary line numbers in AL-131 files } \\
\text { are required. }\end{array}$ \\
\hline 4 & $\begin{array}{l}\text { When desired, user must enter } \\
\text { summary line numbers by hand. }\end{array}$ & $\begin{array}{l}\text { User may direct program to calculate } \\
\text { summary line numbers. }\end{array}$ \\
\hline 5 & $\begin{array}{l}\text { User must manually "clone" and edit } \\
\text { A-A files to create A-B, A-J, or A-E } \\
\text { files. }\end{array}$ & $\begin{array}{l}\text { User may direct program to create A-B, } \\
\text { A-J, or A-E files. }\end{array}$ \\
\hline 6 & $\begin{array}{l}\text { User must explicitly remove write-offs } \\
\text { by "shipping" them and set up the AL- } \\
131 \text { files. The user must manually } \\
\text { "clone" and edit A-M files to create A- } \\
\text { I files when appropriate. }\end{array}$ & $\begin{array}{l}\text { Closing function automatically takes care } \\
\text { of A-M and A-I files. }\end{array}$ \\
\hline 7 & $\begin{array}{l}\text { Decay procedure runs automatically } \\
\text { the last day of the month in the } \\
\text { evening and prints a decay report.. }\end{array}$ & $\begin{array}{l}\text { The user must tell system to run decay } \\
\text { and wait for the results. }\end{array}$ \\
\hline 8 & $\begin{array}{l}\text { Users can "backdate" transactions to } \\
\text { place them in a previous month for } \\
\text { accounting purposes. }\end{array}$ & $\begin{array}{l}\text { There is no "backdate" capability; the user } \\
\text { must be sure to specify the correct } \\
\text { accounting period and transaction date } \\
\text { before entering transactions. Misdated } \\
\text { transactions cannot be corrected. }\end{array}$ \\
\hline 9 & $\begin{array}{l}\text { It is possible to re-run the balance for } \\
\text { a previous accounting period to make } \\
\text { corrections. }\end{array}$ & $\begin{array}{l}\text { It is not possible to re-open a previous } \\
\text { accounting period to make corrections. }\end{array}$ \\
\hline 10 & $\begin{array}{l}\text { Reports formatted for } 81 / 2 \text { by 11 } \\
\text { paper (portrait or landscape format). }\end{array}$ & $\begin{array}{l}\text { Reports are formatted for } 81 / 2 \text { by 14 } \\
\text { paper. }\end{array}$ \\
\hline
\end{tabular}

\subsection{General}

\begin{tabular}{|l|l|l|}
\hline & \multicolumn{1}{|c|}{ COMATS } & \multicolumn{1}{c|}{ LANMAS } \\
\hline 1 & $\begin{array}{l}\text { Automatically assigns transaction } \\
\text { code and user function for each } \\
\text { transaction. }\end{array}$ & $\begin{array}{l}\text { For some transactions (project changes, } \\
\text { shipments, receipts, and adjustments), } \\
\text { user must select an appropriate Type } \\
\text { Inventory Change. }\end{array}$ \\
\hline 2 & $\begin{array}{l}\text { Business date and timestamp } \\
\text { automatically entered for each } \\
\text { transaction. }\end{array}$ & $\begin{array}{l}\text { User must select transaction date from a } \\
\text { calendar displayed on the screen. }\end{array}$ \\
\hline
\end{tabular}




\begin{tabular}{|l|l|l|}
\hline 3 & $\begin{array}{l}\text { Business date and timestamp include } \\
\text { time of day as well as date. }\end{array}$ & $\begin{array}{l}\text { Transaction date does not include time of } \\
\text { date. }\end{array}$ \\
\hline 4 & $\begin{array}{l}\text { Automatically prevents "out-of-order" } \\
\text { transactions. }\end{array}$ & $\begin{array}{l}\text { It is up to the user to ensure that } \\
\text { transactions are entered in the correct } \\
\text { sequence. }\end{array}$ \\
\hline 5 & $\begin{array}{l}\text { The locking scheme requires the user } \\
\text { to wait until the requested item } \\
\text { becomes free. If the item is involved } \\
\text { in another transaction, the user } \\
\text { receives an error message. When the } \\
\text { user enters the product items, the user } \\
\text { may be assured that he has exclusive } \\
\text { control of the source items. }\end{array}$ & $\begin{array}{l}\text { The locking mechanism assumes the item } \\
\text { is free until the user attempts to update it. } \\
\text { If two or more users intend to update the } \\
\text { same item, the race is on! The winner } \\
\text { goes home happy; the losers get to re- } \\
\text { enter their transactions. }\end{array}$ \\
\hline
\end{tabular}

\section{Summary of Gaps}

The following lists the most serious gaps. All gaps may be found in Appendix D.

- $\quad$ LANMAS does not require unique item serial numbers.

- $\quad$ Users are unable to accurately characterize an item.

- $\quad$ LANMAS does not allow a second user to verify a transaction before applying it to the inventory.

- $\quad$ LANMAS does not allow an accountability specialist to review a transaction entered by a user before applying it to an "official" inventory.

- $\quad$ LANMAS does not allow an accountability specialist to make corrections to a previous accounting period once it has been closed.

- $\quad$ LANMAS requires the users to be aware of which accounting period they are to be entering transactions.

- $\quad$ LANMAS performs neither mass limit checking, credible rollup checking as required by DOE Order 474.1, nor ratio checking as required by DOE Std 1027.

- $\quad$ Except at time of receipt, LANMAS does not allow users to place items on "measurement hold." LLNL needs this capability to identify items that must be measured because they are being returned from a process area, having been selected by an inventory sampling program, etc.

- $\quad$ LANMAS does not contain an inventory sampling program. 
- $\quad$ LANMAS does not allow received items awaiting measurement to be moved until the measurement is complete and entered for the item. This conflicts with LLNL procedures that receive an item into a location, place it in storage while awaiting measurement, and then move it to a specific location for measurement, then move it back to storage while the measurement results are being evaluated.

- LANMAS does not automatically determine the MBA and location to which an inventory adjustment is to be charged back.

- $\quad$ LANMAS does not possess the ability to produce item history or genealogy reports.

- $\quad$ LANMAS does not provide a workstation inventory report following each transaction in a workstation.

- $\quad$ LANMAS does not produce a cost report.

- $\quad$ LANMAS does not allow the user to enter generic (many-to-many) process or transform transactions.

- $\quad$ LANMAS does not automatically determine "box loss" or "write-off" resulting from a process transaction.

- $\quad$ LANMAS does not allow items from different DOE projects to be assembled.

- LANMAS does not allow the application of TIDs to non-accountable items that are not in the inventory.

- LANMAS does not store the owner (the person accountable for the item) or the responsible person (the person in possession of the item).

- $\quad$ LANMAS does not have the capability of authorizing users for specific rooms or workstations.

LANMAS Release 2.7 is due out near the end of 2000, and may fully or partially close some, but not all, gaps:

- $\quad$ Peer Review (second user verification)

- Transaction review and approval

- $\quad$ Mass limit checking

- Inventory difference charge back

- $\quad$ Rounding - this is a recognized problem with LANMAS affecting all user sites, so it is really not considered a "gap." 
Future releases of LANMAS may resolve other issues as well. For example, Helen Howell has been gathering requirements for reports related to mass limit checking and transaction review.

Once future releases and their associated documentation are available, we should perform additional analysis regarding the closure of these gaps. 


\section{Conclusions and Recommendations}

This "gap analysis" as uncovered some serious deficiencies in LANMAS in relation to current LLNL MC\&A practice. These deficiencies, or "gaps," may or may not be resolved in future releases of LANMAS. It is therefore our recommendation that we proceed with a gradual, phased integration LANMAS into COMATS that would: 1) utilize LANMAS as a tool for reporting to DOE, NNSA, or to NMMSS; 2) use the existing COMATS interface to be used for day-to-day operational activities; and 3) as the COMATS user-interface is reengineered to run on PC-workstations and to be easier to use and learn, further evaluate the LANMAS interface, taking into account enhancements made to LANMAS as a result of the feedback contained in this report. This phased integration requires the existence of an Automated Programmer Interface module which would allow COMATS users to cause updates to the LANMAS inventory or to get reports from LANMAS via existing COMATS terminals.

To summarize: Use LANMAS to do what LANMAS does best (accounting and inventory); use COMATS to do what COMATS does best (characterization and tracking).

\section{Appendices:}

The following appendices provide additional details:
A. Summary report of the End-to-End Transaction Flow Test as applied to LANMAS
B. List of things that the users did not like
C. List of things that the users liked
D. List of all of the gaps found. 
Appendix A:

\section{End-to-End Transaction Flow Test Applied to LANMAS \\ Summary Report}

\section{Table of Contents}

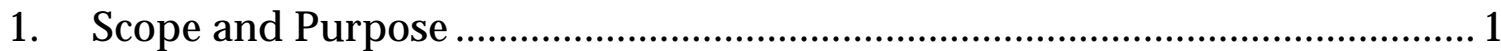

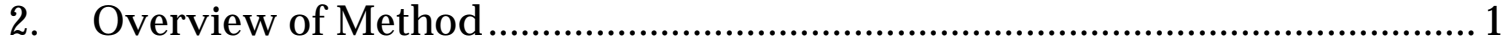

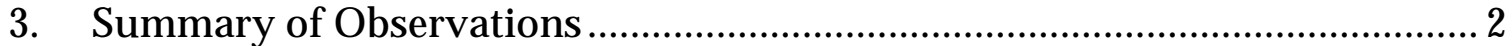

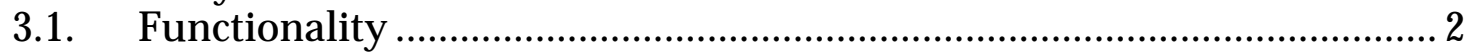

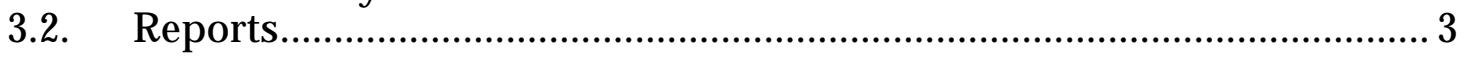

3.3. Differences in Terminology …....................................................... 3

3.4. User Interface ......................................................................... 3

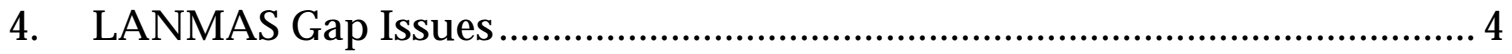

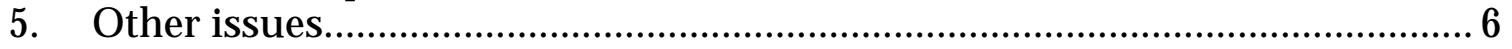

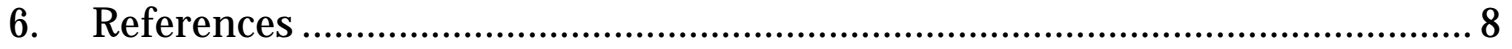




\section{Scope and Purpose}

The goal for this test was to obtain COMATS user feedback on the ease of use and functionality offered by LANMAS. The test was based on a transaction flow test (TFT) which followed a typical lifecycle for items received, processed, stored and shipped, and also included month end reporting. The transaction flow test consisted of a list of user tasks derived from a use case scenario developed by Bruce Watson who interviewed users about their tasks. The TFT was written to be system independent and is planned to be developed into an automated regression test. Although the End-to-End TFT included the most common types of user interactions with the COMATS system, it was not intended to be allinclusive. Dry running of the TFT was performed on COMATS to remove errors from the test. Estimates of the length of time to run the test on COMATS were used to schedule the LANMAS testing. Because of time constraints, actual LANMAS testing consisted of one pass through the End-to-End TFT. Sometimes only a single user had a chance to try a specific LANMAS feature, and only features which supported the functions in the End-to-End TFT were tried. This limited usability observations. To avoid conclusions biased by individual differences, only general results about LANMAS usability, substantiated by multiple users are included in this report.

\section{Overview of Method}

The testing took place from July 10 through 14, 2000 on a LANMAS system installed on a Win/NT PC in Room 1003 of Building 233. Preparation and outbriefing of COMATS users who tested LANMAS took place in the Actinide Conference Room in B233. The testing in Room 1003 was often crowed with observers, testers and developers. Although interactions with the user testers were generally limited to users asking Helen Howell questions and receiving guidance from the Test Assistant, in fact the environment was not controlled, and there were occasional interactions between testers and others in the room. These appeared to have only minor affect on the users. The week was broken up into an initial two-hour introduction to LANMAS session which most of the testers attended, followed by eight user testing sessions, and then a final observer wrap-up session. Each user testing session also included some limited preparation, a session of about an hour on LANMAS, and then an out-briefing interview using a fixed set of questions. The tasks for each session included from one to seven LANMAS transactions. Five sessions had two users working together; the other four had a single user tester. Three users participated in two sessions.

Helen Howell from Savannah River Site conducted the user preparation sessions and gave assistance during testing when asked by the users. The End-To-End TFT was planned and managed by Nancy Storch and Bruce Watson, members of the COMATS SQA team. They were assisted in test preparations and data setup by Charles Parrish, COMATS project leader, and Wally Yee, COMATS developer. Dry run testing of the End-To-End TFT was accomplished on COMATS prior to the LANMAS testing with the help of Vira Okuda, COMATS 
SQA technician. The testing team who observed the users during the test sessions, interviewed them afterwards, shared observations and put this report together cut across several organizations. Bruce Watson and Helen Howell observed every session. Nancy Storch, Cheri Jo Patenaude and Kevin Mahoney provided an additional third or fourth observer for each session. Nancy Storch and Bruce Watson also served as test assistants.

Ten COMATS users who closely followed the End-to-End TFT conducted testing. These users represented typical users from across the Materials Management Groups whose tasks are: materials accountability (three users), measurement and verification (one user), vault operations (two users), Building 332 operations (two users), and fissile material handlers (two users). All of these users were experienced with COMATS; none had seen LANMAS before. Three users were familiar with Win/NT and were comfortable with using a graphical user interface (GUI) to an application like LANMAS. For the others, this environment was mostly a new experience. To help the observers, the users were instructed to "talk aloud" as they went about accomplishing their tasks. They found this easy to do. For additional information on the test design and method refer to: "Usability Testing for LANMAS Gap Analysis" and "Test Assistant Session Outline".

\section{Summary of Observations}

The following sections summarize the hundreds of observations collected throughout the week. They are supported by specific observations documented in "LANMAS/COMATS Gap Analysis: Observations, Summary and Analysis".

\subsection{Functionality}

For the most part, the testers found LANMAS functionality to their liking, saying "Very good, very helpful for performing [their] jobs [as testers]," and "faster and less steps". They noticed features not in COMATS. They especially liked LANMAS' implementation of Grouping, Receiving, Month End Balance, Containerization and Moving 1 .

Certain features appealed to them:

- write-offs and round-offs for month end balancing are more simply handled without resorting to pseudo shipments

- pop-up calendar which supplied the current date, by default

- ability to access needed files in another window concurrently, while LANMAS continued to run, as contrasted with the COMATS environment where MAG users must log in and out to switch back and forth between captive and private accounts

\footnotetext{
${ }^{1}$ Although every tester realized instantly that LANMAS' implementation of moving of items between workstations, especially if they are not in the same MBA, is not totally consistent with MM operations, nonetheless everyone was impressed with and liked the ease and simplicity of its implementation.
} 
Aside from some major shortcomings in LANMAS support of current LLNL operations (discussed under LANMAS Gap Issues), some of the features the users didn't like were:

- the box loss aspects of a split,

- requiring information for a transaction not normally known by the user, e.g., isotope enrichments/weights, or which TIC (Type Inventory Change, DOE defined)

Also the testers felt that LANMAS was a more complicated system than COMATS, but were quick to point out that this perception was probably due to the difference in their familiarity with both systems.

\subsection{Reports}

Of the testers exposed to LANMAS' reporting capabilities (for Receiving, Shipping and Month End Closing), all liked it, and how well it was integrated into LANMAS' functionality. They liked the report formats, and the print preview option, and were very impressed with the ability to search a report from the user interface. However due to time constraints for review, the testers were not sure that the reports shown contained sufficient data or would support their job in their present form. One critical report, the Workstation Inventory Report, is totally missing from the LANMAS repertoire. As an integral part of our operating procedures, the operators routinely post this report on the outside of every workstation.

\subsection{Differences in Terminology}

There were indications that differences in terminology between LANMAS and COMATS affected tester performance. These were often confusing since they related not only to terminology used on the screens, but also to differences in the way the software behaved. Differences were seen in:

- system functionality, e.g., 'Mix' in LANMAS as contrasted with 'Assemble' in COMATS, 'Assemble' in LANMAS as contrasted with 'Group' in COMATS, 'Adjustment' in LANMAS as contrasted with 'Data Correction' in COMATS,

- user interface, e.g., 'Save" Tabs in LANMAS as contrasted with 'Return' (to previous menu) in COMATS, 'Exit' and 'OK' in LANMAS on the Type Inventory Change form as contrasted with 'Update DB' in COMATS.

\subsection{User Interface}

Success in trying out the new user interface depended on the tester's prior Windows/NT experience, on the complexity of the task under consideration, and whether or not the tester worked alone, or with another tester as a teammate. One of the observers was a LANMAS expert and trainer and provided help to the testers when, and if, they asked. Testers were encouraged however to try to perform transactions on their own before asking for help. 
On the whole, the testers found the LANMAS graphical user interface (GUI) "easy to learn," fast, and comfortable if not from the outset, certainly by session's end. They adjusted to using the mouse for: clicking, dragging and selecting. Most users learned the user interface quickly, and by session's end they were used to it and noticeably more proficient with it. They felt that "With very little training [they] would like [the user interface] over COMATS." It was observed that most testers were able to find their way back when lost. It had been expected that testers would become lost as they had had only a brief introduction to LANMAS and no practice before starting to use it during their test sessions.

Nevertheless the users did experience some difficulties with the user interface and were quite vocal about their frustrations. Many of these arose from unfamiliarity with Windows/NT and inexperience using GUI's. Also testers were mystified by the meanings of some of the buttons and field labels, e.g., "Selected Line 1", "Select Line." appeared on the same screen.

The testers exhibited a lot of uncertainty about the flow of steps in LANMAS functions; that is, the GUI was of little help in figuring out the flow and sequence of steps. Testers were often uncertain what to do next, whether or not the function was complete and whether or not they were done. Certain screens were noticed to be especially confusing; these were for the Mix, Split and Receive functions. Whereas the COMATS user interface has evolved over many years to match LLNL user needs in a very compact and tailored way, LANMAS offers more general capabilities and seems to require more knowledge from the user.

\section{LANMAS Gap Issues}

The following are the main issues raised regarding LANMAS' ability to support current LLNL operations and materials accountability needs. These came from observations and concerns raised during preparation sessions and outbriefing discussions with users. The list is not intended to be inclusive, as it was prompted for the most part by the TFT tasks that users were assigned. Additional details are available in the "Gap Summary" document.

\begin{tabular}{|l|l|l|}
\hline & Issue & \multicolumn{1}{c|}{ Description } \\
\hline 1. & $\begin{array}{l}\text { Box Loss } \\
\text { calculation }\end{array}$ & $\begin{array}{l}\text { Need automatic Box Loss calculation } \\
\text { "Kill if zero" is not sufficiently explicit to deal with } \\
\text { box loss. User needs to always be notified and } \\
\text { asked if that is as expected. }\end{array}$ \\
\hline 2. & Characterization & $\begin{array}{l}\text { LLNL's system of breaking this down into shapes, } \\
\text { forms, container, etc., is not available for entry or } \\
\text { retrieval in LANMAS. }\end{array}$ \\
\hline
\end{tabular}




\begin{tabular}{|c|c|c|}
\hline & Issue & Description \\
\hline 3. & $\begin{array}{l}\text { Concurrent } \\
\text { operations }\end{array}$ & $\begin{array}{l}\text { LANMAS uses optimistic locking. If someone has } \\
\text { updated a certain record between the time the user } \\
\text { pulled the record and the time the database is to be } \\
\text { updated, it flags the user that the record has been } \\
\text { changed. This may prove awkward to a user who } \\
\text { might have to reenter a transaction. }\end{array}$ \\
\hline 4. & $\begin{array}{l}\text { History Tracking } \\
\text { and Reporting }\end{array}$ & $\begin{array}{l}\text { Need to be able to track parts, generating a parts } \\
\text { genealogy and print a mix history. }\end{array}$ \\
\hline 5. & $\begin{array}{l}\text { Mass Limit } \\
\text { Checking }\end{array}$ & $\begin{array}{l}\text { Need Mass Limit Checking with every item move. } \\
\text { Some capabilities are being added to LANMAS release } \\
2.7 \text {, but it is not clear to what extent they will meet our } \\
\text { needs. } \\
\text { - Also need ability to temporarily change mass limits }\end{array}$ \\
\hline 6. & $\begin{array}{l}\text { Measurement } \\
\text { Hold }\end{array}$ & $\begin{array}{l}\text { Need ability to place items on Measurement Hold } \\
\text { - Need to allow user to be notified of measurement } \\
\text { hold, but allow the transaction to continue. }\end{array}$ \\
\hline 7. & $\begin{array}{l}\text { Mixing items } \\
\text { from different } \\
\text { projects }\end{array}$ & $\begin{array}{l}\text { LANMAS is unable to Assemble (Mix) items from } \\
\text { different projects }\end{array}$ \\
\hline 8. & Moves & $\begin{array}{l}\text { - Need to be able to terminate a move in progress } \\
\text { - LANMAS allows more than one item to be moved } \\
\text { at a time in a single transaction; this conflicts with } \\
\text { our mass limit checking requirements. } \\
\text { Moves Between MBAs: } \\
\text { The LANMAS method of initiating and } \\
\text { completing/terminating a move between MBA' is not } \\
\text { compatible with MM operations. } \\
\text { - LANMAS allows an item to be sent to a different } \\
\text { MBA without any location having first been } \\
\text { specified; this is a safety and criticality issue, } \\
\text { because no mass limits will have been checked } \\
\text { during the initiation of the move. } \\
\text { Moves within an MBA: } \\
\text { - Need to be able to do with } 2 \text { steps. } \\
\text { - Want to define location on "move from" rather than } \\
\text { just on "arrive at". }\end{array}$ \\
\hline 9. & $\begin{array}{l}\text { Naming } \\
\text { Conventions }\end{array}$ & $\begin{array}{l}\text { Differences between what is acceptable to LANMAS } \\
\text { and what is customary in COMATS will need to be } \\
\text { resolved in planning a transition to using LANMAS }\end{array}$ \\
\hline
\end{tabular}




\begin{tabular}{|c|c|c|}
\hline & Issue & Description \\
\hline & & $\begin{array}{l}\text { and before transferring LLNL's database into } \\
\text { LANMAS. }\end{array}$ \\
\hline 10. & Reports & $\begin{array}{l}\text { It appears that a significant amount of work will have } \\
\text { to be done on reports to accommodate Materials } \\
\text { Management. } \\
\text { - LANMAS does not have the characterization details } \\
\text { that our users use to search/report on } \\
\text { characterization information } \\
\text { - Need summary printout of workstation contents } \\
\text { - Need to customize distribution lists }\end{array}$ \\
\hline 11. & $\begin{array}{l}\text { TID } \\
\text { administration }\end{array}$ & $\begin{array}{l}\text { LANMAS functionality does not support MM TID } \\
\text { administration particularly in regards to security issues } \\
\text { and TID naming convention. } \\
\text { - Need TID verifier to log in with password, } \\
\text { otherwise any operator could enter any other } \\
\text { operator name as the verifier. } \\
\text { - Need to allow clerk to record application of TID } \\
\text { - COMATS' TID's are named alphanumerically, } \\
\text { whereas LANMAS' are named numerically. }\end{array}$ \\
\hline 12. & TPSS & $\begin{array}{l}\text { LLNL operations require a TPSS mode of operation. } \\
\text { Future releases of LANMAS will have "Peer Review" } \\
\text { and "Peer Verification" features. Further information } \\
\text { about the details of these is needed to judge the extent } \\
\text { to which they will accommodate LLNL requirements. }\end{array}$ \\
\hline 13. & $\begin{array}{l}\text { Unique } \\
\text { identifiers }\end{array}$ & $\begin{array}{l}\text { LLNL requires unique item (part) identifiers (serial } \\
\text { numbers). Unknowingly users can reuse the LANMAS } \\
\text { identifiers they assign to things such as items and } \\
\text { containers. }\end{array}$ \\
\hline 14. & Measurements & $\begin{array}{l}\text { LANMAS requires an item to be measured before it can } \\
\text { be moved. }\end{array}$ \\
\hline
\end{tabular}

\section{Other issues}

These issues were thought to be less critical than the Gap Issues and are more for planning.

\begin{tabular}{|l|l|c|}
\hline & Issue & \multicolumn{1}{c|}{ Description } \\
\hline 15. & Monitor size & 21" monitors are recommended for LANMAS \\
\hline
\end{tabular}




\begin{tabular}{|c|c|c|}
\hline & Issue & Description \\
\hline 16. & Packaging & $\begin{array}{l}\text { If material handlers have to destroy an item's } \\
\text { packaging in order to remove it; in LANMAS, the } \\
\text { packaging will need to be explicitly destroyed, } \\
\text { otherwise it will remain in the inventory as a } \\
\text { container. }\end{array}$ \\
\hline 17. & Round-off & $\begin{array}{l}\text { Method of round-off may be different and needs } \\
\text { clarifying }\end{array}$ \\
\hline 18. & Terminology & $\begin{array}{ll}\text { Clarity and/or conversion needed for: } \\
\text { - } & \text { SubMBA } \\
\text { - } & \text { Add Material } \\
\text { - } & \text { Execute } \\
\text { - } & \text { Detailed Matection Adjustment Type (DMT) } \\
\text { - } & \text { Material } \\
\text { - } & \text { Location } \\
\text { - } & \text { Six } \\
\text { - } & \text { Accept to MBA } \\
\text { - } & \text { Kill on Zero } \\
\text { - } & \text { Set New Weights to Zero } \\
\text { - } & \text { Delete } \\
\end{array}$ \\
\hline 19. & Training & $\begin{array}{l}\text { Our users would need extensive training before } \\
\text { putting LANMAS into operation. Although LANMAS } \\
\text { has a good User Manual, there were indications that } \\
\text { LLNL users would generally not utilize it. } \\
\text { - Users requested both lecture and hands-on, real } \\
\text { life situation, training for switching to LANMAS. } \\
\text { - Complex tasks (like receive and send) will need } \\
\text { detailed procedures to guide users. }\end{array}$ \\
\hline 20. & User Interface & $\begin{array}{l}\text { Additional improvements in the LANMAS user } \\
\text { interface would make it easier to use } \\
\text { - On-line help } \\
\text { - Switch off balloon help } \\
\text { - Better help messages } \\
\text { - Consistency throughout in user interaction } \\
\text { - Clearer terminology } \\
\text { - Consistency in terminology }\end{array}$ \\
\hline
\end{tabular}




\section{References}

The following references are available on a limited basis from the COMATS document server.

“COMATS Use Cases”, Bruce Watson, June 20, 2000; AllOfCOMATS_v17.1

“Gap Summary”, Bruce Watson, July 21, 2000; GapSummaryFinal_v2

"LANMAS/COMATS Gap Analysis: Observations, Summary and Analysis", Test Observer Team, (Some sections are restricted to Test Observer Team members), July 24, 2000; Observatoins_Final_v2.7

“Observations Summarized", Bruce Watson, July 21, 20000;

Ovservations_Summarized_v3

“Test Assistant Session Outline", Nancy Storch, June 20, 2000; Test Assistant Session OutlV2

“Tester Usability Session Info and Questionnaire”, Nancy Storch, June 20, 2000, UT Questionnaire

"Transaction Flow Test \#1", Bruce Watson and Charles Parrish, July 24, 2000;

Trans_Flow_test-1.xls_v8

“Usability Test Observer Notesheet", Nancy Storch, June 20, 2000; UT Test Observer Notesheet

“Usability Testing for LANMAS Gap Analysis", June 20, 2000; Gap_Analysis_UT_v4.doc

“Womb to Tomb Test-1", Bruce Watson, June 20, 2000; WoToTo-1_v6.1 
1 "Activate Other Options" is awkward, non-intuitive, non-standard

2 "Am I done?" "Is it done?" common comment

3 "Assembly" in COMATS is called "Mix" in LANMAS.

4 "Create Part" and "Find Matches" use same screen but require different input

5 "Find Matching Items" and "Create New Item" are buttons both on the Selection screen

6 A radio button labeled 'Execute' is non-standard interface-a menu or tool button to guide user is more standard

7 A user can easily assign a wrong Comp Code to an item. Does not support our restricted selection method of doing characterization.

8 A warning box mechanism would be helpful for lenthy, data entry intense operations and procedures

9 Adding TID's and creating containers are separate steps [in LANMAS but not in COMATS]

10 After finishing an operation on an item, the testers often failed to "Exit" inadvertently returning to previous screen/menu.

11 All mouse selects are accomplished with a single click except on the TIC selection screen where a double click is required

12 Almost all testers were unable to tell when an operation was complete despite prior familiarization. However, they were by sessions end.

13 Almost no tester was facile or even familiar with the concepts of a multifunctional, tabbed screen.

14 Application lost weights which were entered by user during split before the transaction was completed and the user had to reenter them.

15 Blue DMT columns input not marked (???)

16 Change date field in Ship step to read "Use current or later date"

17 Columns (cells) filled in Red imply that something is in error with its contents

18 COMATS users are used to doing everything on one screen with only a few options

19 Confusing. Many choices of buttons when doing a Receive. Not sure which one to pick next.

20 Confusion in meaning and intent of "Accept To MBA" which comes up while moving and item between MBA's

21 CTRL key awkward for selecting multiple items

22 Date request panel appears too often

23 Distribution on Ship report is automatic in $\mathrm{C}$ but not in $\mathrm{L}$

24 Even though the user knew what he wanted to do but didn't find it apparent or obvious how to go about doing it

25 Helen stopped creation of TID to avoid problem when MBA not assigned. If not, the users would have gotten stuck without warning. (recognized bug)

26 Illegal data not caught until Assembly (Mix) operation, i.e., isotope wt. > element wt. on auxilliary items.

27 It's not always obvious what has been done and what remains to be done (pending) 


\section{Observation}

28 It's not obvious in what order things need to be done in general, but especially for mix, split, ship, receive

29 It's not readily obvious how to set the 'To' and 'From' items during an Assembly (Mix)

30 LANMAS allowed tester to unknowingly create two containers with exactly the same name.

31 LANMAS does not have the characterization details that our users use to search/report on characterization information, such as contaminents. There may be some workarounds.

32 LANMAS is more complex than COMATS

33 LANMAS is not as automatic as COMATS as regards splits, e.g., it requires isotope information, explicit box loss

34 LANMAS messages sometimes don't fit the situation, e.g., on the 'Select TIC' screen the message "Put items in Container" was displayed when the container had just been unloaded.

35 LANMAS needs mass limit checking

36 LANMAS needs to be more novice friendly as regards error/help msgs

37 LANMAS needs TPSS and a more restrictive inter mba move function

38 LANMAS seemed slow while using notepad

39 LANMAS software is more complex than COMATS's software

40 LANMAS uses Detailed Material Types (DMT) which our users are not familiar with. Needed help to relate MT to DMT.

41 M100 not present in the locations configuration

42 Make sure to warn users against ever entering anything higher than an 'unclassified' classification level

43 Measurement hold lacking is a real problem

44 Missing a progress bar and/or other warm fuzzies would help/convince the user that the system is processing and not out to lunch.

45 Mix screen very cumbersome and overwhelming.

$46 \mathrm{Mix} /$ Split screens are confusing as regards defining needed data-too many options irrelevant to the task at hand

47 Much information is automatically provided by $\mathrm{C}$ but not by $\mathrm{L}$, e.g., the TIC's

48 Need more prose and more instructions in the Month End Closing step

49 Not clear chat information needs to be defined to create a new item (MBA, subMBA, location)

50 Not clear on split where the new item is defined.

51 Our operators will find it cumbersome to always have to click both "Set New Weights to Zero" and "Kill if Zero"

52 Predefined default distribution list for header on shipping report

53 Problem in selecting froma scrolling list. User not sure how to highlight selection: with arrow, single, or double click. (May indicate an inconsistency in UI)

54 Process flow on the Shipping UI not intuitive, which is partly a matter of familiarization 


\section{Observation}

55 Puzzled when information entered and terms different from what user was accustomed to (expected to "add" after receiving, meaning of "execute")

56 Received numerous isotopic weight errors doing split and unable to determine where the problem was without help.

57 Shipments are more complicated in L than in $\mathrm{C}$

58 Shipping UI is confusing

59 Some inconsistency in terminology throughout LANMAS, i.e. an item is referred to as "material" in the move, but as "item" in split.

60 Some warning messages were confusing and intimidating, e.g. the one about the possibility that a large number of seals have been selected

61 Stumbled over assigning location and subMBA on move.

62 Summary Screen: items that need input should be grouped in the visible section of the screen

63 System crash with run-time error halted the testing session.

64 Tabs were basically unfamiliar to the testers and difficult to use

65 Terminology differences: location vs workstation

66 Tester asked how to go back on several occassions

67 Tester believes said, "This waiting for a screen to pop up will get an FMH into trouble."

68 Tester confused about the intent and meaning of "Selected Line 1" and "Select Line" both present on the same screen

69 Tester confused by LANMAS's mixed metaphores, i.e., 'drag and drop' versus button click.

70 Tester confused by message from mouse's right button.

71 Tester confused when item selection list was presented in alphabetical order; he was expecting numerical order.

72 Tester did not feel that the GUI was very intuitive, but admitted a complete lack of NT experience

73 Tester didn't realize he had not set weights to 0 and killed the item with save (first attempt only)

74 Tester feels that the MM/COMATS way of characterization and containerization is simpler than using LANMAS [in their stead]

75 Tester felt COMATS is much easier and simpler than LANAMS, but volunteered that this was probably just the result of the disparity in familiarity with each system.

76 Tester felt that LANMAS required many more key strokes to complete comparable operations using COMATS

77 Tester found that in general the report formats were different than expected and did not present sufficient data

78 Tester had trouble ordering steps to create new items, then define from item, then entering weights

79 Tester had trouble relating function to screen and kept trying to make the present screen's buttons perform functions controlled by other screens.

80 Tester kept looking for on-line help but found none

81 Tester often failed to realize that a task step had been completed. 


\section{Observation}

82 Tester repeatedly asked for help with the split function

83 Tester repeatedly clicked save after every data entry.

84 Tester repeatedly failed to select each element type when entering isotope data during a split

85 Tester repeatedly made the same entry flows 'mistakes'

86 Tester said, "Why does it keep asking for the date?"

87 Tester tried to change information on a previously completed 741

88 Tester unsure of whether to use "Remove All" or "Delete All" on certain screens

89 Tester used radio button to determine which fields could be modified and which not during the split

90 Tester was able to load one container with items (1st group), but unable to figure out how to pull 2nd container to load it (2nd group)

91 Tester was often mystified by the presence of optional fields on the "Item Selection" screen.

92 Tester was unsure if the reports shown to him would support his job.

93 Testers confused between "Kill On Zero" and "Set New Weights To Zero"

94 Testers confused by the button labels in the Assembly (Mix) operation

95 Testers inadvertently exited w/o saving their work.

96 Testers need a little more instruction on the use of tabs to move from screen to screen during a function as opposed to exiting and starting over.

97 The * and ** buttons among the "Assign" and "Assign All" buttons was very puzzling to all testers.

98 The appearance of the Transaction Number information panel implies completion when such is not the case, e.g., in

99 The button marked "Set Selected to 0" to effect an Assembly (Mix) eluded all testers despite prior familiarization with

100 The flow of user interactions to accomplish complex tasks is not easy to recognize.

101 The meaning of "Save" is not clear

102 The sequence of steps necessary to do a Move is not obvious.

103 The tester needed to be more NT savy, e.g., had trouble with the Select-then-do screen operations, as well as the use of the menu bar to initiate LANMAS functions.

104 The tester seemed to need a defined, linear, single purpose procedure to follow to complete a task; he did not seem comfortable in a multi-functional, highly flexible, non-linear environment. All though he knew what the tasks were required to complete a test step, he had trouble determining the order of the sequence of tasks.

105 The testers didn't follow the sequence of steps described by the TFT.

106 The testers often didn't realize that a function was complete.

107 The UI needs to adopt one uniform format

108 The user test procedure was confusing when data was included and the task was not well defined, i. e. containerization data but no instructions as to whether or not user was to put the item in a container. 
109 There was an error in the PU isotope \% enrichment given to the user.

110 TIC double click is a stumbling point

111 TID's were in an MBA not in agreement with TFT or else thay hadn't been created.

112 Unsure what data correction meant in LANMAS.

113 User asked, several times, how to return to the previous screen. Seemed to want an easier way than going back to the menu.

114 User was able to select a button when insufficient information had been selected. It confused the user to receive an error message after the fact. Recommend greying buttons when the requirements for an action have not been met.

115 while creating a container, tester entered its name on the selection screen expecting it to be carried over to the next container screen.

116 Would like MBA xfer to be explicit about destination workstation at the outset rather than having it specified at receive time.

117 Would like to be able to turn off help boxes when not needed. 


\section{Observation}

1 All testers recovered from mistakes quickly, e.g., thinking that "Remove Selected" removed the item from the MBA).

2 Although the tester fumbled, stumbled and generally got lost as if in a maze, he nonetheless prevailed and was able to complete the test steps with minimal assistance from the Trainer

3 Application easy to learn, comfortable, self explatory. Only needed once or twice through to learn. With very little training felt would like over COMATS.

4 Being able to use a wild card in the Find Matches function was very nice

5 Box loss taken care of automatically

6 Caught on quickly to GUI and expressed satisfaction in accomplishment (use of arrow to highlight, use of pop-up calendar, where to enter $\mathrm{AB}$ ).

7 Closing is a no-brainer, a piece of cake

8 COMATS being a TPSS system usually results in new users being trained on the job by experienced users (as a TPSS pair). This gives the illusion that it is easier to learn than it actually is.

9 Completed the task (Receive Item) 30 min early.

10 Error messages make sense, provide help and were very good in general

11 Even a novice, non NT savy tester was able to perform the complex Ship function with minimal to moderate amount of coaching

12 Even w/o preview, tester was able to pick up and go through flow

13 Even with problems experienced, felt the application was straight forward and easy to use.

14 Extremely easy to use for an NT savy tester

15 LANMAS automatically compares/balances current inventory against transaction history on a daily basis

16 LANMAS is better than COMATS, has features not in COMATS

17 LANMAS's style of moves between MBA's is not a show stopper, but will require procedural adjustments in MM

18 Liked having all element/isotope information available

19 Liked pull down menus with select as opposed to simply typing in information

20 Liked the ability to enter isotopic \% to calculate isotope weights.

21 Liked the ability to maximize the screens

22 Liked the drag and drop feature a lot for containers

23 Low level of frustration.

24 Moves (within and between MBAs) went smoothly without any hitches.

25 Much easier to do receive: faster and less steps.

26 Much easier to transmit AL131 file to DOE Contractor or 740 file to NMSS

27 Not having to do pseudo shipments for box loss, etc. is very nice 
28 Not having to log in/out back and forth between a captive account and a user account is really helpful

29 Pull downs were very nice

30 Rate of concept acquisition seemed very high for all testers.

31 Really easy to learn, easy to operate, and fast

32 Recognized flow of system: 1) Select items to perform functions, 2) transact upon

33 Report print previews are very nice

34 Reports are very good

35 Seemed adequate for a change

36 Seemed to like pop-up calendar feature.

37 Some initial confusion on GUI features (highlighted columns for entry fields, entering search criteria); but liked these after realizing how they worked.

38 Tester especially liked the Search/Select (Find Matches) screen/functionality and how it was integrated into LANMAS.

39 Tester especially likes LANMAS's containerization

40 Tester liked exploring both UI and Fn, found doing so easy, adopting an inquisitive and positive attitude while doing so.

41 Tester liked the NT print screen feature

42 Tester likes being able to search (pull) based on different selection criteria

43 Tester really liked the 131 and 741 reports

44 Tester really liked the drag and drop mechanism

45 Tester thought the LANMAS containerization implementation was excellent.

46 Tester was able to extricate himself when lost in the weeds

47 Tester was quite comfortable with using error messages as a guide

48 Tester was quite comfortable with clicking to find stuff

49 Testers discovered incomplete or erroneous values which they had inputted on their own

50 Testers were very pleased $\mathrm{w}$ themselves at various points when able to accomplish tasks w very little assistance

51 That [LANMAS] was simple

52 The 2-person team did well finding its way around even though they made mistakes; successfully applied and destroyed TID's without any assistance.

53 The COEI search function was very, very nice.

54 The pulldowns are helpful

55 The UI paradigm was a little baffling at first, but users adapted quickly.

56 There was nothing about LANMAS that the tester didn't like 


\section{Observation}

57 Took some getting used to UI. Initially unaware of scrollable information off to the right of the screen which needed to be changed. Liked that highlighting and ordering of columns can be set by user.

58 Tool tips were helpful

59 Two users worked well together, sometimes answering each other's questions.

60 User already familiar with the PC interface fel comfortable.

61 Very easy to use

62 Very good, very helpful for performing testers' jobs.

63 Win NT unfamiliarity did not appear to be a significant problem.

64 With training the UI would be very helpful

65 With training the UI would not be hard to use

66 [LANMAS] more friendlier [than COMATS] 
COMATS Function

1 Authorizations

2 Classified Parts

3 Classified Parts

4 Closing - Decay

\section{Information}

1 Information

2 Information

3 Information

4 Information

5 Information

6 Measurements

7 Measurements

8 Measurements

\section{Measurements}

10 Movements

11 Movements

12 Movements

13 Movements

14 Movements - MBA Transfer

15 Movements - Move Loc

16 Movements - Move Loc

17 Process

18 Process

19 Process

20 Process

21 Process

22 Process - Assembly

23 Process - Assembly

24 Process - Assembly

25 Process - B332

26 Process - Characterization

27 Process - Characterization

28 Process - Characterization

\section{Description}

LANMAS does not allow user authorization for specific room and workstation

LANMAS has no built-in capabilities for producing bar-code labels

LANMAS was not designed to track classified parts

As one of the steps in the closing process, the user must initiate the decay and acknowledge its completion

LANMAS does not maintain "quota"; it uses the project number directly

LANMAS does not maintain the "owner" in the COMATS sense; LANMAS only maintains the NMMSS owner code

LANMAS does not maintain the "responsible person"

LANMAS material names (serial numbers) need not be unique

There are differences between what is acceptable in LANMAS and what is customary in COMATS

LANMAS does not allow entry of comments

Chargeback to MBA and loction not automatic in LANMAS

LANMAS does not have the capability of placing items on "Measurement Hold".

LANMAS does not keep track of measurements other than the method and instrument used in the inventory record

Received items "Awaiting Measurement" are frozen; no transactions (even movements) may take place on the item until it is measured

LANMAS does not support COMATS-style limit checking

LANMAS does not support Room TPSS (Room Cat 1 or Credible Rollup) checking

LANMAS does not support "sum of fractions" or ratio limit checking

LANMAS does not support the concept of intermediate locations

LANMAS does not specify location on send step - location must be specified at receive

Cannot terminate a move in process

In LANMAS, all movements within an MBA are one-step

LANMAS does not allow process transactions (mix, split, transfer) to involve items belonging to different projects

LANMAS does not calculate isotope weights based in source and destination element weight and source isotope isotope weights

LANMAS does not support a generic transform or process transaction

LANMAS users must be aware of the isotopic composition with doing mix and split transactions

Split resets product weights after user returns to the Selection Criteria to select or create new items

LANMAS does not allow "box loss" in Mix transactions

LANMAS does not total weights as a default

The user may need to be aware of the detail material type to perform a mix transaction

LANMAS does not automatically manage "box loss" (BX) resulting from process transactions

IDC and ANSI Scrap code are item, not material type, dependent

LANMAS does not maintain shape and contaminant information

There is no characterization tree - LANMAS presents IDCs as a linear list 
COMATS Function

29 Process - Split

30 Process - Transform

31 Process - Transform

32 Receive

33 Receive

34 Receive

35 Reports

36 Reports

37 Reports

38 Reports

39 Reports - 741s

40 Reports - Cost

41 Reports - History

42 Reports - History

43 Reports - Programmed 44 Reports - Programmed 45 TIDs

46 TIDs

47 TIDs - Apply

48 TIDs - Apply

49 TIDs - Issue

50 TIDs - Issue

51 TIDs - Issue

52 TIDs - Ship

53 Transactions

54 Transactions

55 Transactions

56 Transactions

57 Transactions - Review 58 Transactions - Review

\section{Description}

LANMAS does not support proportional splits

Because they are items, user-created "WO@" cannot be negative

LANMAS does not automatically manage explicit write-offs (WO@) resulting from transforms

LANMAS does not warn the user if the element weight, isotope weight, and enrichment are inconsistent

LANMAS expects AL-131 files being imported to contain summary material types, not detail material types

LANMAS expects AL-131 files with alternating B and C records; i.e., B001, C001, B002, C002, etc LANMAS does not produce classified markings; it is the responsibility of the user to either load classified paper or hand-stamp the output

No customized distribution list

No Workstation Inventory Report

Windows/NT has limited capability to run off-line batch jobs

Reports are formated for 8-1/2 by 14 (legal) paper

LANMAS does not have the capability of getting a cost report as used at LLNL

LANMAS has no built-in capabilities of getting part history and genealogy reports

LANMAS part history does not indicate which items produced the item of interest, or what items were created from the item of interest

LANMAS programmed inventory reports do not allow the specification of weight ranges or category

Users cannot save filters for later use in programmed reports

LANMAS requires the TID user to specify the user who physically performed the operation, even if it is the user himself/herself

Need TID verifier to log in with password (2.7 Peer Review)

A TID may only be applied to one location

LANMAS has no capability of applying TIDs to items, containers, or locations that are unknown to LANMAS

LANMAS does not permit the transfer of issued seals to another MBA without first returning them to "for use", transferring them to the destination MBA, and then re-issuing them

TIDs are issued to the MBA they are in when issued

TIDs can only be issued at the MBA level; issuing to a specific room is not possible

LANMAS does not automatically "ship" TIDs when the items to which they are attached are also shipped

LANMAS 2.6 does not support second user verification (potential

LANMAS does not permit ANY transactions on an item this inside a container (except TIDs

LANMAS optimistic locking may require user to re-enter transaction if conflict occurs

The user must enter the effective date for each transaction as the activity date; time cannot be entered

If a transaction is declined, LANMAS rolls it back

The products of a transaction are not available until the transaction has been approved 


\section{Appendix D:}

Gaps

\# COMATS Function

59 Transactions - Review
Description

Transaction Review is not supported for LANMAS 2.6 